\title{
THE MECHANICAL BEHAVIOUR OF NEW LONG-SPAN HOLLOW-CORE ROOFS BASED ON ALUMINUM ALLOY HONEYCOMB PANELS
}

\author{
MEHANSKO OBNAŠANJE NOVIH STREH Z VOTLIMI JEDRI IZ \\ SATASTIH PANELOV ZA VELIKE RAZPONE, IZDELANIH NA \\ OSNOVI ALUMINIJEVIH ZLITIN
}

\author{
Caiqi Zhao, Jun Ma, Shengchen Du* \\ Key Laboratory of Concrete and Prestressed Concrete Structure, Ministry of Education, School of Civil Engineering, Southeast University, 2\#, \\ Southeast University Road, Nanjing 210096, China
}

Prejem rokopisa - received: 2018-04-15; sprejem za objavo - accepted for publication: 2018-12-06

doi: $10.17222 /$ mit.2018.075

\begin{abstract}
This article proposes a new type of spatial structure that is based on the principle of an aviation structure skin force bearing. The structure consists of honeycomb panels and specialized connecting pieces to spatially combine the honeycomb panels and form a novel skeleton-free hollow-core roof system (referred to as a "honeycomb panel structural system" (HPSS)). To evaluate the stitching results of the new structure, its connection performance, failure mechanism and limiting load were examined, and the full-scale samples that were designed and manufactured from two sets of HPSS were employed to conduct the experimental research. The results indicated that the new structure has a high spatial stiffness and loading capacity. The failure mode of the two test specimens comprises the shear damage of the connector and the buckling failure of the honeycomb panel. The existing rectangular sandwiched honeycomb panel buckling theory cannot correctly reflect the plastic deformation or failure of the sandwiched material, this paper obtained the analysis method for the honeycomb panel buckling characteristic value that is consistent with practical conditions. Using different simulation methods, the comparative analysis results revealed that the finite-element coupling method proposed in this paper can adequately simulate the actual operating state of the connector between two honeycomb panels. This method is feasible, highly efficient, and provides a theoretical basis for future revision of the design rules for this new type of spatial structure.
\end{abstract}

Keywords: long-span hollow-core roof, HPSS, connection performance, full-scale test

Avtorji predlagajo uporabo novega tipa prostorske strukture, ki temelji na strukturah, uporabljenih v aviaciji za izdelavo nosilnih delov trupa in kril letal. Strukture so sestavljene iz panelov v obliki satovja in specialnih veznih delov (spojk), ki prostorsko kombinirajo panele v nove oblike strešnih konstrukcij, okrajšano imenovane HPSS (angl.: Honeycomb Panel Structural System). Avtorji so raziskovali različne oblike novih struktur, njihove vezavne lastnosti, mehanizme poškodb in porušitve na vzorcih naravne velikosti, ki so bili oblikovani in izdelani iz dveh setov HPSS. Eksperimentalni rezultati so pokazali, da imajo nove strukture veliko prostorsko togost in nosilnost. Način porušitve dveh izdelanih vzorcev obsega strižno deformacijo spojk (veznih vijakov) in poškodbe zaradi uklona panelnega satovja. Uklonska deformacijska teorija ne more popolnoma opisati dejanske plastične deformacije pričujočega pravokotnega sendvič-satastega panela oziroma njegove končne porušitve. Na osnovi analitične metode so avtorji določili karakteristične vrednosti uklona panelnega satovja, ki se ujemajo z dejanskimi pogoji. Avtorji so z uporabo različnih simulacijskih metod in rezultatov primerjalne analize odkrili, da predlagana kombinirana metoda na osnovi končnih elementov ustrezno simulira dejansko operativno stanje povezave med dvema izbranima satastima paneloma. Metoda je izvedljiva, visoko učinkovita in podaja teoretične osnove za revizijo zakonov oblikovanja tega novega tipa prostorskih struktur.

Ključne besede: strehe z votlimi jedri za velike razpone, HPSS, učinek vezave, preizkusi v naravni velikosti.

\section{INTRODUCTION}

The honeycomb structure that bees create is a very reasonable spatial structure. ${ }^{1-9}$ A composite aluminium alloy honeycomb panel (the aluminium honeycomb core that is sandwiched between the upper layer and the lower layer of aluminium alloy sheets) has the advantages of light weight, high stiffness, and noise and heat insulation. ${ }^{10-14}$ The panel is a typical representative of a highperformance sheet material; it is extensively employed in aviation, high-speed trains, ships and other fields. ${ }^{15-18}$

*Corresponding author e-mail:

dushengchen@hotmail.com
This article presents a new type of spatial structure that consists of honeycomb panels, i.e., the use of specialized connectors for an aluminum honeycomb panel space assembly to construct a "novel, skeleton-free, hollow-core, roof system" that does not have any loadbearing rods ${ }^{19}$ (referred to as a "honeycomb panel structural system" (HPSS)). The basic configuration of the system is equivalent to an enlarged honeycomb panel, as shown in Figure 1a. Studies have shown that ${ }^{20-22}$ this novel roof system combines load bearing and enveloping into one body that is lightweight and has high stiffness and excellent seismic performance as well as favourable constructional and physical properties. In single-floor industrial plant buildings of various span lengths (Figure 
1b), the HPSS is especially suitable for long-span roof structures, such as gravity-sensitive gymnasiums and airplane hangars (Figure 1c), which demonstrates broad application prospects.

In the study of aluminium alloy lattice shells, Wang Hong et al. ${ }^{23}$ analysed the stability of a Schwieder-type aluminium alloy lattice shell with a 40-m span under different loads in detail. All these results showed that destabilization was the main failure mode of the shell structure. Using a single-layer K8 spherical lattice shell structure as an example, Gui Guoqing et al. ${ }^{24}$ used a numerical simulation to analyse the geometric nonlinear stability of an aluminium alloy lattice shell. They discussed the influence of the vector-to-span ratio, the load distribution and the supporting condition on the stable bearing capacity of the lattice shell. Hongbo Liu et al. ${ }^{25}$ analysed with a nonlinear finite method to clarify the stability performance of aluminium-alloy single-layer latticed shell. The suggested values of the rise/span ratio and the initial imperfection were presented. Sugizaki et al. ${ }^{26}$ tested four single-layer aluminium alloy spherical lattices using reduced-scale models. They studied the effects of three factors on the steady bearing capacity. The influence of the nodal domain was taken into account in the finite-element analysis. ${ }^{27}$ Xiaonong Guo et al. ${ }^{28}$ investigated the resistance of aluminium alloy gusset joint plates. Zechao Zhang et al. ${ }^{29}$ analysed the performance of an aluminium alloy single-layer latticed shell. With the geometrical nonlinear finite-element method, the stability coefficient and the weak parts of the structure were obtained considering the initial imperfections and the material nonlinearity.

In the study of the honeycomb structure's stability, Attard and Hunt ${ }^{30}$ considered the shear deformation of the panel and the core honeycomb layer. Using piecewise first-order beam theory, they analyzed the overall buckling of the honeycomb structure. Bourada ${ }^{11}$ and Tounsi et al. ${ }^{12}$ studied the instability of a honeycomb core with a uniform wall thickness under uni- and bidirectional inplane compression and out-of-plane compression. Using experimental studies and numerical simulations, A. Boudjemai $^{31}$ and Amri et al. ${ }^{32}$ studied the macroscopic deformation and plastic instability of a honeycomb structure with uniform wall thicknesses under unidirectional in-plane compression.

It is obvious that the existing studies focus on the aluminum-alloy lattice shell structure or the honeycomb panel itself. Research on the new type of hollow-core roof structure that is based on the aluminum alloy honeycomb panel introduced in this paper is lacking. What are the total stiffness and loading capacity of the new structure that is assembled by connecting as large number of honeycomb panels? Existing differences between the mechanical properties and the failure mechanisms of similar spatial structures should be explored. Two sets of full-scale hollow-box samples with a plane dimension of $1 \mathrm{~m} \times 3 \mathrm{~m}$ and a structural height of $300 \mathrm{~mm}$ were designed and manufactured. The stitching connection performance and ultimate bearing capacity of the new structure were investigated to determine the connections between the two panels, explore the failure mechanism of the structure, and evaluate and verify the reliability of the finite-element simulation methods between the panels. The results provide design rules for a new spatial structure with a theoretical basis for future revisions.
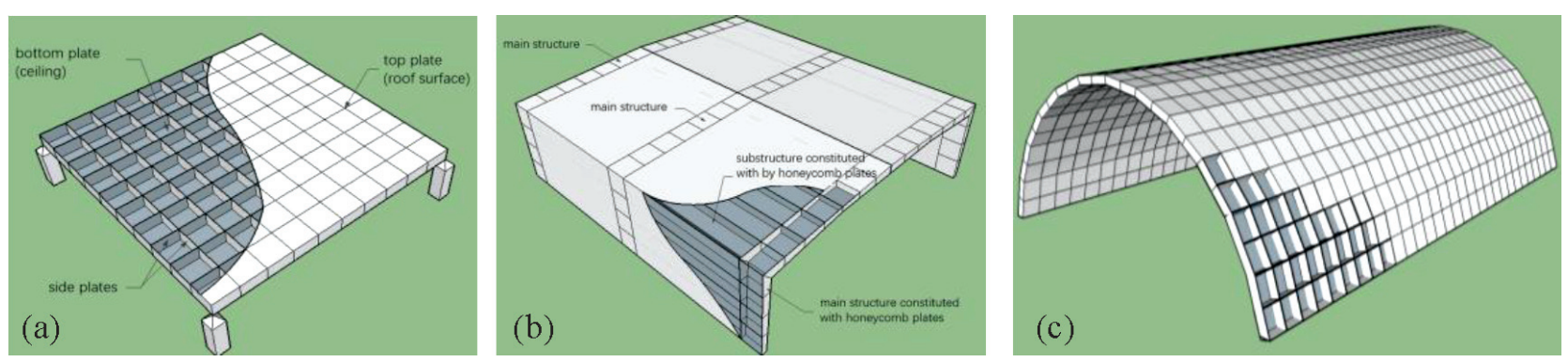

Figure 1: Typical form of the HPSS: a) flat honeycomb-panel roof system, b) door-frame type honeycomb-panel roof system, c) long-span curved roof system
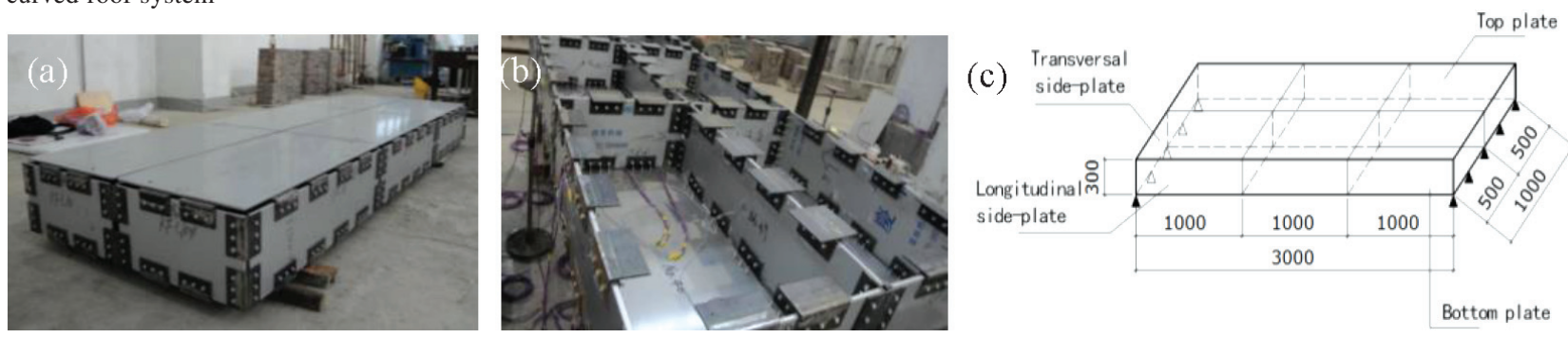

Figure 2: Full-scale specimen overview: a) the total appearance, b) internal structure, c) geometrical dimensions 


\section{EXPERIMENTAL PART}

\subsection{The design and fabrication of the full-scale sample}

Two sets of samples of the hollow-box type are employed. The plane dimensions of each sample are $1 \mathrm{~m} \times$ $3 \mathrm{~m}$, the structural height of each sample is $300 \mathrm{~mm}$, and each sample is formed by stitching together 29 aluminum honeycomb panels with specialized connectors (Figure 2). The plane dimensions of the top and bottom plates (six panels for each plate) are $0.5 \mathrm{~m} \times 1 \mathrm{~m}$; the dimensions of the vertical side plate is $0.3 \mathrm{~m} \times 1 \mathrm{~m}$ (nine panels), and the dimensions of the horizontal side plate is $0.3 \mathrm{~m} \times 0.5 \mathrm{~m}$ (eight panels).

The thickness of the honeycomb panel used for the sample construction was $10 \mathrm{~mm}$, the thicknesses of the upper and lower surfaces of the aluminum alloy sheet was $1 \mathrm{~mm}$, the thickness of the honeycomb core layer was $8 \mathrm{~mm}$, the $\mathrm{n}$ of the honeycomb core was $6 \mathrm{~mm}$, and the wall thickness was $0.05 \mathrm{~mm}$. To facilitate the connection, a reinforced edge frame was set up around the periphery of each honeycomb panel. Two box-type samples (denoted as SJ1 and SJ2) were designed according to the different types and number of bolts on the connectors. Their plane dimensions and the specifications are equivalent to the material utilized for the honeycomb panel.

The connectors between the side-plates of specimen $\mathrm{SJ} 1$ and the base of the plates and the connectors between the bottom plates employed an ordinary bolt connection with a diameter of $6 \mathrm{~mm}$. The connectors between the plate tops and the connectors between the plate tops and the side-plates utilized a hexagonal head self-drilling self-tapping screw connection with a diameter of $4 \mathrm{~mm}$. Three bolts were installed on each side of the connector.

The connectors between the side-plates of specimen SJ2 and the base plates, and the connectors between the base plates employed high-strength bolts of 8.8 grade. In the $1 / 3$ segment of the mid-span, where the stress is significant, five high-strength bolts with a diameter of $8 \mathrm{~mm}$ were added to each side of the connector. Highstrength, hexagonal, self-drilling, self-tapping bolts with a diameter of $6 \mathrm{~mm}$ were used between the top plates. High-strength bolts were constructed by specialized electric tools to ensure a seamless tight fit between the plates and the connectors.

\subsection{Loading and testing methods}

At the one-third points of the box-type specimen, two concentrated loads were applied through the distribution beam (Figure 3a). The hydraulic jack performed realtime load monitoring and data acquisition through the force sensors. Simple support conditions at both ends were implemented by installing rollers and a backing plate. To measure the bearing capacity of a specimen and the displacement and strain distribution of a honeycomb panel, a strain gauge rosette was attached to the front and back of the longitudinal side-plates, the transversal sideplates, top plate and the bottom plate of the box-type specimen. The displacement sensor was installed near the mid-span and supporting seat. The test site is shown in Figure 3b.

\section{RESULTS}

\subsection{Failure pattern of the specimen SJ1}

In the third loading process, when the load was increased to $10 \mathrm{kN}$, the specimen $\mathrm{SJ} 1$ began to produce a sound. With an increase in load to $12 \mathrm{kN}$, the pressure sensor exhibited a sudden decrease in the load with a bang, and the mid-span displacement became significantly larger, which indicates that the specimen has reached its limit. Since the bending moment and shearing force have the largest value at $1 / 3$ of the span, the connector bolts on the bottom plate, under the action of the bending moment, were vertically sheared across the sheet. For the connectors on the side plates, due to the combined effect of bending moment and shearing force, the bolt was bi-directionally sheared along the direction of the span and the height of the specimen. The connection bolt on both sides, in the direction of the height initially exhibited shearing failure, which caused a sudden increase in the load on the connectors on the bottom plate, the connection bolts were successively sheared, and the specimen lost loading capacity and was declared a failure (Figure $\mathbf{4 a}$ and $\mathbf{4 b}$, the sheared bolts are marked with red arrows).

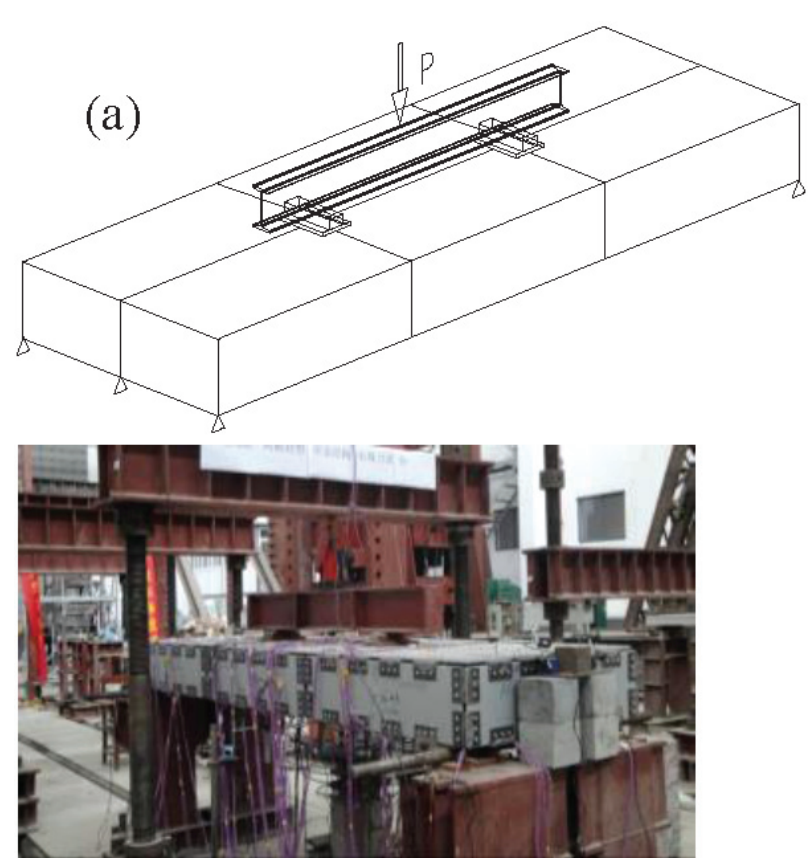

Figure 3: Measuring point layout and loading site: a) loading diagram, b) the testing site 

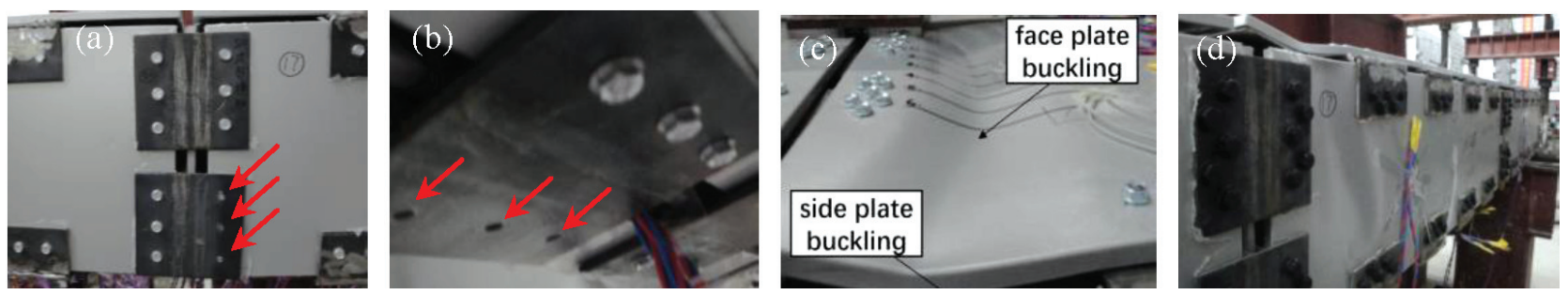

Figure 4: Failure patterns of specimen: a) the bolts on the side plates were sheared, b) the bolts on the bottom plate were sheared, c) compressive buckling deformation of the top plate, d) deformation on the side plates

\subsection{Failure pattern of the specimen SJ2}

When the specimen SJ2 was loaded to $38 \mathrm{kN}$, the honeycomb panel was significantly deformed, and the local stress concentration of the specimen was evident. As a result, the honeycomb core was extruded and deformed by the face plate, and local tensile cracking occurred between the honeycomb core and the face plate.

When the load was increased to $40 \mathrm{kN}$, a slight buckling deformation began to appear at the one-third point of the top plate. When the load was increased to $48 \mathrm{kN}$, the buckling deformation of the specimen was distinct, and depressed buckling occurred (Figure 4c). As the load increased to $52 \mathrm{kN}$, the buckling deformation on the plate top significantly expanded. At the occurrence of the depressed buckling, a protruded buckling deformation also occurred at the side plates (Figure $4 \mathbf{d}$ ).

When the load increased to $55.7 \mathrm{kN}$, the hydraulic jack was persistently pressured, and the force sensor exhibited a decrease in load, whereas the deflection in the mid-span continued to increase, which indicates that the specimen has reached its limit.

\section{DISCUSSION}

\subsection{Analysis of experimental results}

An ordinary bolt connection was employed between the two plates of specimen SJ1; thus, the connection bolts were sheared during the damage of the specimen. At this point, the deformation of the aluminum-alloy honeycomb-panel was not significant, and the ultimate bearing capacity of the specimen SJ1 was only $12 \mathrm{KN}$. There forecast prior to the damage was not distinct, which revealed the typical characteristics of brittle failure. Since the high-strength bolt connection was employed between the plates of specimen SJ2, no shearing failure occurred in all the bolts of the connector until specimen failure. Under the action of a vertical internal force, buckling deformation occurred on the top plate in the pressure zone of the box-shaped specimen until the honeycomb panel completely buckled and lost stability. Specimen SJ2 had a maximum measured ultimate bearing capacity of $55.7 \mathrm{KN}$, which was 4.64 times the ultimate bearing capacity of specimen SJ1, and displayed evident characteristics of ductile buckling damage.
The new hollow-core roof structure that was assembled from honeycomb panels has a high total stiffness and load-bearing capacity, which demonstrates excellent structural performance. However, effective measures must be taken to ensure that the connectors do not precede the buckling damage of the honeycomb panel and that the lightweight and high-strength properties of the honeycomb panel can be fully applied to realize the high load-bearing capacity of the proposed structure.

The experimental results also revealed that the mid-span deflections of the two specimens differ by only $1.4 \mathrm{~mm}$ under the ultimate load, which indicates that the total stiffnesses of the two specimens were relatively close. However, the ultimate bearing capacity of the two specimens varied significantly. When specimen SJ1 was damaged prior to the buckling of the honeycomb panel in the pressure zone, the load-bearing capacity was lost due to the insufficient anti-shearing strength of the bolt on the connector. The advantages of the light weight and high strength of the honeycomb panel cannot be fully utilized. The connection performance of the connectors has a critical role in the novel structure.

\subsection{Finite-element simulation and theoretical analysis of the specimen}

\subsubsection{Finite-element analysis}

When applying the finite-element method to the structural analysis of a new prefabricated honeycombpanel hollow-core roof, the following two issues must be addressed: (1) the reasonable equivalency of the honeycomb-panel; and (2) the reasonable simulation method for the connectors between honeycomb panels. Due to the complex internal structure of an aluminum honeycomb panel and the lack of a honeycomb cell library in existing software, if the interior of the honeycomb core is also divided into subunits in the design (Figure 5), then proceeding with the analysis will be difficult due to the vast number of cells. Prior to the finite-element analysis of the specimen, the aluminum alloy honeycomb panel is equivalent to the anisotropic plate in this paper according to the honeycomb-panel theory (Figure 6).

The following three different simulation methods were employed in this paper for the comparison and analysis of the specimens: 


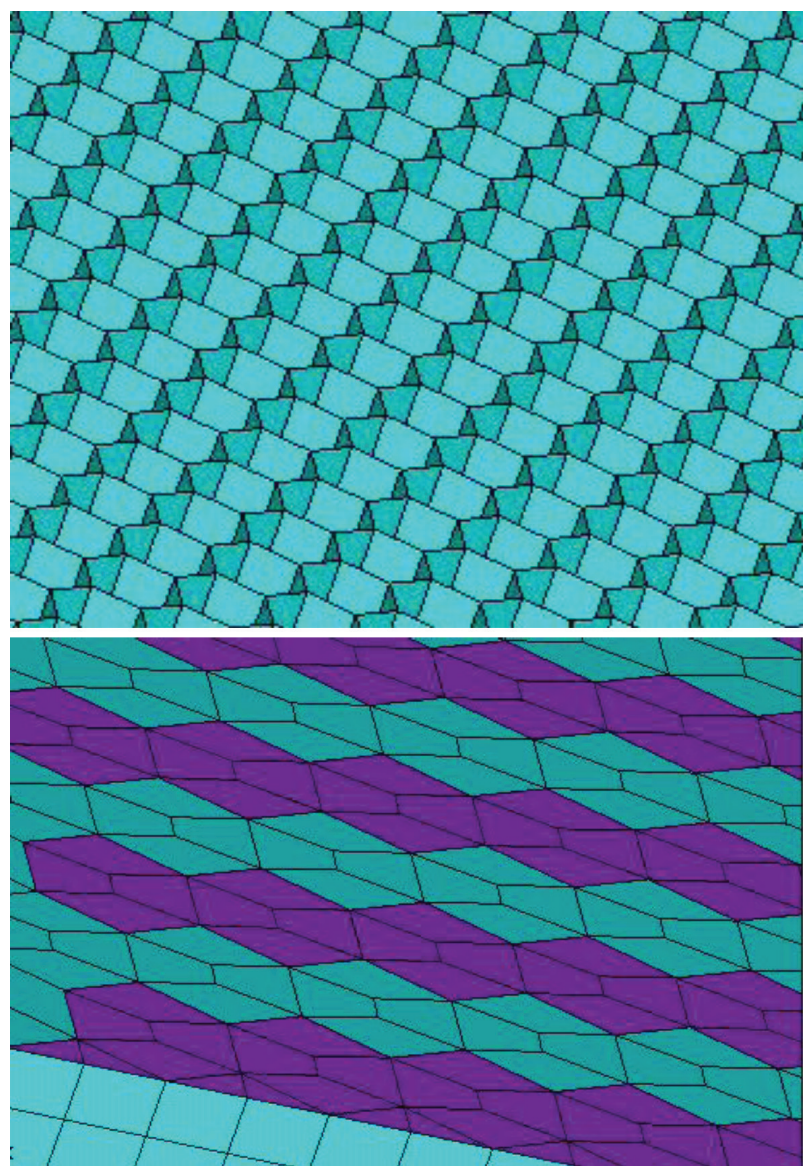

Figure 5: Refinement model of the honeycomb core

(1) Fully coordinated finite-element method. Due to the approximate application of the fully coordinated method, the calculation model cannot fully reflect the actual connections between the panels. Therefore, the analysis results tend to have large deviations with low accuracy.

(2) Connection unit method. The method requires specialized experiments or many calculation trials to obtain reasonable stiffness parameters of the connection unit.

(3) Finite-element coupling method. Due to numerous connectors in the actual structure, refining the model for each connector (including the bolts on the connectors) will generate a large workload of modeling and cell division, and the computation time will multiply, which significantly reduces the efficiency of the struc-

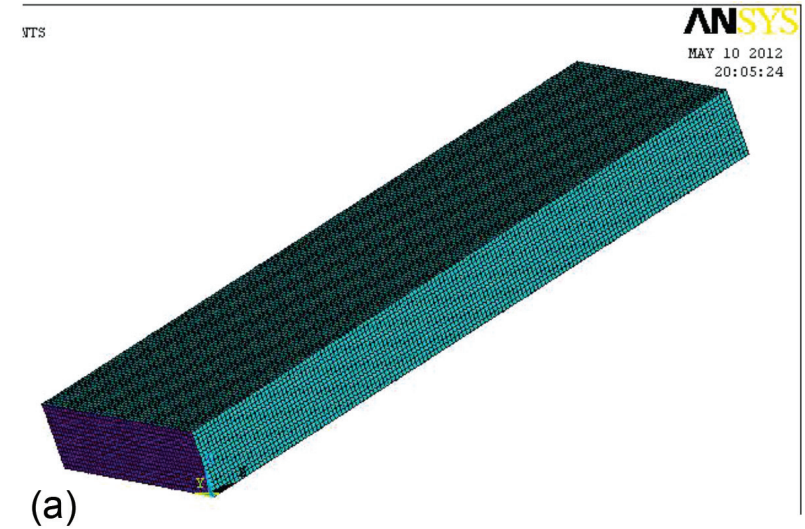

(a)

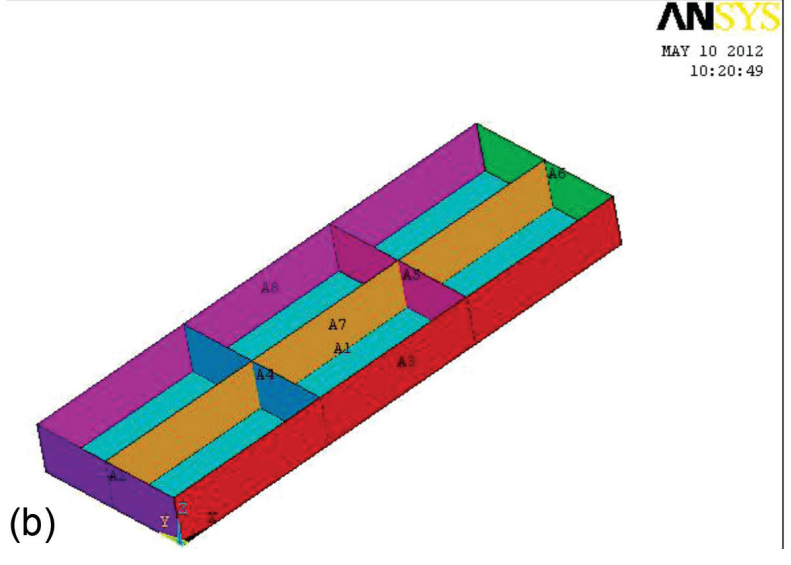

Figure 6: Analysis model of the box-type specimen

tural analysis. Therefore, if a finite-element connection method that approximates the simulation of the connection performance is utilized, then the time of structural analysis will be substantially reduced, and the computational efficiency can be improved. Considering the characteristics of the intermittent connections of the connectors in the honeycomb-panel structure, and considering that the connectors were maintained in contact with each other during the loading process, this paper presents the degree of freedom coupling method to approximate and replace the connector contact. The analysis results are displayed in Table $\mathbf{1 .}$

As shown in Table 1, the modeling of the fully coordinated finite-element method is the simplest model; however, because the error is large, this method cannot be chosen. Although the error from the connection unit method is not large, it requires many calculation trials and experiments prior to the structural analysis to deter-

Table 1: Computation results of specimen SJ2 for different connection simulation methods

\begin{tabular}{|c|c|c|c|c|c|c|c|}
\hline \multirow{2}{*}{ Parameter } & \multirow{2}{*}{ Test value $E$} & \multicolumn{2}{|c|}{$\begin{array}{c}\text { Fully coordinated } \\
\text { finite-element method }\end{array}$} & \multicolumn{2}{|c|}{$\begin{array}{l}\text { Finite-element coupling } \\
\text { method }\end{array}$} & \multicolumn{2}{|c|}{ Connection unit method } \\
\hline & & $\begin{array}{l}\text { Calculation } \\
\text { value } F_{1}\end{array}$ & $\begin{array}{c}\text { Error } \\
\mathrm{D}_{1}\end{array}$ & $\begin{array}{l}\text { Calculation } \\
\text { value } F_{2}\end{array}$ & $\begin{array}{c}\text { Error } \\
\mathrm{D}_{2}\end{array}$ & $\begin{array}{l}\text { Calculation } \\
\text { value } F_{3}\end{array}$ & $\begin{array}{l}\text { Error } \\
\text { D }\end{array}$ \\
\hline Deflection / mm & 8.70 & 6.28 & $27.8 \%$ & 8.15 & $6.32 \%$ & 7.67 & $11.8 \%$ \\
\hline plate stress /MPa & 23.17 & 18.65 & $19.5 \%$ & 25.05 & $-8.1 \%$ & 26.01 & $-12.3 \%$ \\
\hline
\end{tabular}

Note: $\mathrm{D} 1=(\mathrm{E}-\mathrm{F} 1) / \mathrm{E} ; \mathrm{D} 2=(\mathrm{E}-\mathrm{F} 2) / \mathrm{E} ; \mathrm{D} 3=(\mathrm{E}-\mathrm{F} 3) / \mathrm{E}_{0}$ 
mine the reasonable stiffness parameters of connection unit. Therefore, it is not suitable for analysis and the design of large engineering projects. The finite-element coupling method generated the smallest error; building the coupling set in the modeling stage is convenient, which satisfies the requirements of general engineering accuracy.

\subsubsection{Theoretical analysis of ultimate bearing capacity}

When specimen SJ2 failed, the experimental state indicated that external buckling occurred on the top plate of the box-type specimen, where the pressure zone exists, and the conversion stress on the top plate was only $40 \mathrm{MPa}$ at this point, which was significantly less than the strength limit of the aluminum honeycombpanel; that is, the buckling of the sheet occurred prior to the strength failure. Therefore, research on the stability of a honeycomb panel under the action of internal vertical pressure is crucial for the analysis of the ultimate bearing capacity of a specimen.

Using the top plate of a honeycomb panel that is in the pressure zone of a box-type specimen, as an example, the buckling bearing capacity of a four-side simply supported honeycomb sandwich panel was analysed with respect to the lateral uniform load. ${ }^{33}$ The plane dimension of this sheet is $1 \mathrm{~m} \times 0.5 \mathrm{~m}$, the thickness is $h=10 \mathrm{~mm}$, and the effect of the uniform load is on the short edge. Substituting the relevant parameters of the honeycomb panel into the following formula:

$$
p=\frac{\frac{D \pi^{2}}{b^{2}}\left(1+\beta^{2} m^{2}\right)^{2}}{\beta^{2} m^{2}\left(1+\delta_{2}+\delta_{2} \beta^{2} m^{2}\right)}
$$

In the equation, $D$ is the buckling stiffness; $b$ is the plate width; $b$ is the length-width ratio of the plate; and $m, d_{1}$, and $d_{2}$ are the undetermined constants.

When $m=2$, the minimum value of $413.3 \mathrm{~N} / \mathrm{mm}$ was chosen for $\mathrm{p}$ after the calculation trial. Therefore, the theoretical solution of the buckling bearing capacity of the honeycomb panel is $P_{\text {cr }}=413.3 \mathrm{~N} / \mathrm{mm} \times 500 \mathrm{~mm}=$ $206.65 \mathrm{kN}$. The theoretical solution obtained from the analysis of the honeycomb panel and the finite-element results given by the three equivalent theories are listed in Table 2.

The analysis results indicated that both the sandwiched-core-plate theory and the honeycomb-plate theory do not substantially differ from the theoretical solutions in solving the buckling characteristic values of the honeycomb panel. According to the Reissner theory, the metal panel primarily bears the tensile and compressive stress of the honeycomb panel. As shown in Table $\mathbf{2}$, the reduced compressive stress on the upper and lower plates of the honeycomb panel under the action of the buckling load are (206.65, 188.42, 223.18, and 229.35) $\mathrm{MPa}$. Regardless of the theoretical solutions or finite-element solutions, the compressive stresses of the upper and lower plates have exceeded the ultimate bearing strength of the aluminum alloy.

Although the buckling characteristic values can be obtained by an analysis based on the theory of sandwiched honeycomb core buckling, the finite-element analysis and stress calculation of the aluminum alloy honeycomb panels indicate that the strength of the aluminum alloy sheet buckled prior to the buckling of the honeycomb panel. This phenomenon indicated that the geometric defects of the sheet material and the premature failure of the internal core material have a significant influence on the load-bearing capacity of a metal honeycomb panel.

The middle core layer of a honeycomb panel is composed of thick and soft aluminum foil. The application of the honeycomb core buckling theory and the three equivalent theoretical finite-element analyses did not consider whether the core material is plasticized or in failure, or whether the material property change was caused by the collapse of the core (that is, the buckling analysis was only performed for the entire sheet without considering the nonlinearity of the material). This finding does not correspond to the practical situation.

When the face plate is combined with the core to form the metal honeycomb panel, the bearing capacity of the entire panel is increased to a certain extent but will not reach the value that is listed in Table 2. In the finiteelement analysis, amendments are necessary. First, the upper limit value of the internal and external failure of the honeycomb must be determined. The failure refers to the maximum load value sustained by the honeycomb prior to collapse. According to the upper limit formula of the plastic collapse stress presented by Gibson et al., ${ }^{25}$ the upper limit value of the plastic collapse stresses in all directions are $\sigma_{\text {ypl }}=0.0053 \mathrm{MPa}, \tau_{\text {xypl }}=0.0017 \mathrm{MPa}$, $\tau_{\text {xzpl }}=0.250 \mathrm{MPa}$, and $\tau_{\text {yzpl }}=0.217 \mathrm{MPa}$ (the subscript refers to the direction of the stress). The finite-element analysis of the buckling load for the honeycomb panel with the plate dimension of $1 \mathrm{~m} \times 0.5 \mathrm{~m}$ was performed. The stress failure criterion was used to control the stress change of the aluminum alloy panel and the honeycomb

Table 2: Comparison of the theoretical solution and the finite-element solution of a honeycomb plate $(1 \mathrm{~m} \times 0.5 \mathrm{~m})$ for buckling bearing capacity

\begin{tabular}{|c|c|c|c|c|c|c|c|}
\hline \multirow[b]{2}{*}{ Parameter } & \multirow{2}{*}{$\begin{array}{l}\text { Theoretical } \\
\text { solution }(L)\end{array}$} & \multicolumn{2}{|c|}{ Sandwich core plate theory } & \multicolumn{2}{|c|}{ Honeycomb plate theory } & \multicolumn{2}{|c|}{ Equivalent plate theory } \\
\hline & & $\begin{array}{l}\text { Calculation } \\
\text { value } T_{1}\end{array}$ & $\begin{array}{c}\text { Error } \\
\mathrm{D}_{4}\end{array}$ & $\begin{array}{l}\text { Calculation } \\
\text { value } T_{2}\end{array}$ & $\begin{array}{c}\text { Error } \\
\mathrm{D}_{5}\end{array}$ & $\begin{array}{l}\text { Calculation } \\
\text { value } T_{3}\end{array}$ & $\begin{array}{c}\text { Error } \\
\mathrm{D}_{6}\end{array}$ \\
\hline$P_{\mathrm{cr}} / \mathrm{KN}$ & 206.65 & 188.42 & $8.8 \%$ & 223.18 & $-8.0 \%$ & 229.35 & $-11.0 \%$ \\
\hline
\end{tabular}

Note: D4 = $(\mathrm{L}-\mathrm{T} 1) / \mathrm{L} ; \mathrm{D} 5=(\mathrm{L}-\mathrm{T} 2) / \mathrm{L} ; \mathrm{D} 6=(\mathrm{L}-\mathrm{T} 3) / \mathrm{L}$. 
equivalent core to solve the internal buckling load of the actual honeycomb core sheet.

When the load on the honeycomb core aluminum foil reaches the upper collapse stress limit of $0.0053 \mathrm{MPa}$, the support to the face plate is lost, which causes buckling of the honeycomb panel and the entire panel. After the collapse of the honeycomb core, the compressive stress on the metal face plate is $49.46 \mathrm{MPa}$ in the $\mathrm{x}$-direction. This stress can be obtained after conversion, where the load was $P=30.23 \mathrm{kN}$; then, the ultimate bearing capacity of the specimen was $P_{\mathrm{cr} 1}=2 P=60.46 \mathrm{kN}$. This value is approximately $29.26 \%$ of the theoretical honeycomb panel buckling value $(206.65 \mathrm{kN})$; compared with the tested value of $P_{\mathrm{cr} 2}=55.69 \mathrm{kN}$, the difference is $7.89 \%$.

These analysis results indicate that the rectangular sandwiched honeycomb plate buckling theory cannot correctly reflect the plastic change or failure of the sandwiched core material or the influence of the sandwiched core material property change on the face plate load. Only the total honeycomb panel working performance was considered, which is not consistent with a practical situation. After considering the material property of the honeycomb core, the honeycomb panel internal surface buckling controlled by the upper limit of honeycomb collapse stress given by Gibson et al. ${ }^{34}$ can yield honeycomb panel internal surface buckling characteristic values that are relatively consistent with a practical situation.

When calculating the ultimate bearing capacity of a honeycomb-panel structure, the buckling performance of the honeycomb panel must be analyzed and calculated under compression to determine whether the controlling factor is strength or stability when the structure enters plastic deformation and reaches the ultimate state. If the controlling factor is stability, then the honeycomb panel buckling performance will be analyzed by considering the influence of internal honeycomb collapse on panel buckling performance.

\section{CONCLUSIONS}

This paper proposes a new type of hollow-core roof system (referred to as a HPSS) that comprises the assembly of aluminum honeycomb panels solely via sheet stitching using specialized connectors. The connection performance and ultimate bearing capacity were experimentally analyzed by the finite-element theory. The following conclusions were obtained:

(1) A novel prefabricated hollow-core roof structure has a high spatial stiffness and ultimate bearing capacity, which reveals the structural characteristics of light weight and high strength. A comparison of the test results indicates that effective measures are necessary to ensure that the connection components do not fail before honeycomb panel buckling or strength failure and to fully explore the light weight and high strength characte- ristics of the honeycomb panel to ensure adequate load capacity.

(2) The failure mode of the two test specimens comprises the shear damage of the connecting components and the buckling failure of the honeycomb panel inner surface. The connection bolts had been sheared off prior to the failure of specimen 1 , whereas the honeycomb panel did not exhibit distinct deformation; the specimen exhibited typical brittle failure characteristics. Since specimen 2 was connected by high-strength bolts, the ultimate bearing capacity was significantly higher than the ultimate bearing capacity of specimen 1 . The connection components were intact when the panel failure occurred; the top plate at the compression zone had significant compressive buckling deformation; and the specimen exhibited reasonable ductile buckling failure characteristics. Therefore, the connection performance of the connection components is critical to the load performance of the proposed novel prefabricated structures.

(3) The study results for the honeycomb panel inner surface buckling performance indicate that the existing rectangular sandwiched honeycomb panel buckling theory cannot correctly reflect the plastic deformation or failure of the sandwiched material or the conducive influence of the sandwiched material on plate-buckling resistance. These results are not consistent with the practical working state of the honeycomb panels. By considering the honeycomb core material's properties and controlling the honeycomb panel inner surface buckling with the ultimate honeycomb collapse stress, this paper obtained an analysis method for the honeycomb panel inner surface buckling characteristic value that is consistent with practical conditions.

(4) Rational simulation of the connections between honeycomb panel materials is the key to the design of this type of prefabricated honeycomb panel structure. Using different numerical simulation methods, the comparative results of the finite-element analysis for the box-type specimen indicated that the coupled finite-element method proposed in this paper can adequately simulate the practical working state of the connection components between the honeycomb panels. This method is feasible, highly efficient, and provides a theoretical basis for future revision of the design rules for this new type of spatial structure.

\section{Acknowledgments}

This study was supported by the Natural Science Foundation of China under grant no. 51578136.

\section{REFERENCES}

${ }^{1}$ J. X. Chen, Q. Zu, G. Wu, J. Xie, Review of beetle forewing structure and biomimetic applications in China(II), Mater. Sci. Eng. C, 55 (2015), 620-633, doi:10.1016/j.msec.2015.04.045 


\section{ZHAO et al.: THE MECHANICAL BEHAVIOUR OF NEW LONG-SPAN HOLLOW-CORE ROOFS ...}

${ }^{2}$ J. X. Chen, Twenty years of the beetle elytron bionic research (I) interior structure, model and integrated honeycomb plate, Scientia Sinica Technologica, (2018), doi:10.1360/N092017-00208

${ }^{3}$ W. Y. Tuo, C. F. Wan, X. M. Zhang, Shear test method for and mechanical characteristic of short basalt fiber reinforced polymer composite materials, J. Appl. Polym. Sci., 135 (2018), doi:10.1002/ app. 46078

${ }^{4}$ J. X. Chen, X. M. Zhang, Y. Okabe, J. Xie, M. Y. Xu, Beetle elytron plate and the synergistic mechanism of a trabecular-honeycomb core structure, Sci. China: Technol. Sci., (2018), doi:10.1007/s11431018-9290-1

${ }^{5}$ Z. J. Zhang, J. X. Chen, M. A. Elbashiry, Z. S. Guo, X. D. Yu, Effect of changes in the structural parameters of bionic straw sandwich concrete beetle elytron plates on their mechanical and thermal insulation properties, J. Mech. Behav. Biomed. Mater., 90 (2018), doi:10.1016/j.jmbbm.2018.10.003

${ }^{6}$ X. D. Yu, L. C. Pan, J. X. Chen, X. M. Zhang, P. X. Wei, Experimental and numerical study on the energy absorption abilities of trabecular-honeycomb biomimetic structures inspired by beetle elytra, J. Mater. Sci., (2018), doi:10.1007/s10853-018-2958-0

${ }^{7}$ W. Y. Tuo, J. X. Chen, Z. S. Wu, J. Xie, Y. Wang, Characteristics of the tensile mechanical properties of fresh and dry forewings of beetles, Mater. Sci. Eng. C, 65 (2016), 51-58, doi:10.1016/j.msec. 2016.04.025

${ }^{8}$ J. X. Chen, C. Gu, S. Guo, C. Wan, X. Wang, J. Xie, X. Hu, Integrated honeycomb technology motivated by the structure of beetle forewings, Mater. Sci. Eng. C, 32 (2012), 1813-1817, doi:10.1016/ j.msec.2012.04.067

${ }^{9}$ X. M. Zhang, C. Liu, J. X. Chen, Y. Tao, Y. Gu, The influence mechanism of processing holes on the flexural properties of biomimetic integrated honeycomb plates, Mater. Sci. Eng. C, 69 (2016), 798-803, doi:10.1016/j.matdes.2015.07.060

${ }^{10}$ Y. X. Ma, Y. D. Zheng, H. Y. Meng, W. H. Song, X. F. Yao, H. X. Lv, Heterogeneous PVA hydrogels with micro-cells of both positive and negative Poisson's ratios, J. Mech. Behav. Biomed. Mater., 23 (2013), 22-31, doi:10.1016/j.jmbbm.2013.03.021

${ }^{11}$ J. H. Dirks, V. Dürr, Biomechanics of the stick insect antenna: Damping properties and structural correlates of the cuticle, J. Mech. Behav. Biomed. Mater., 4 (2011), 2031-2042, doi:10.1016/j.jmbbm. 2011.07.002

${ }^{12}$ K. J. Koester, H. D. Barth, R. O. Ritchie, Effect of aging on the transverse toughness of human cortical bone: Evaluation by R-curves, J. Mech. Behav. Biomed. Mater., 4 (2011), 1504-1513, doi:10.1016/ j.jmbbm.2011.05.020

${ }^{13}$ A. E. Donius, A. Liu, L. A. Berglund, U. G. K. Wegst, Superior mechanical performance of highly porous, anisotropic nanocellulose-montmorillonite aerogels prepared by freeze casting, J. Mech. Behav. Biomed. Mater., 37 (2014), 37, 88-99, doi:10.1016/j.jmbbm. 2014.05.012

${ }^{14}$ J. X. Chen, C. L. He, C. L. Gu, J. X. Liu, C. W. Mi, J. S. Guo, Compressive and flexural properties biomimetic integrated honeycomb plates, Mater. Des., 64 (2014), 214-220, doi:10.1016/j.matdes. 2014.07.021

${ }^{15}$ J. X. Chen, W. Y. Tuo, X. M. Zhang, C. L. He, J. Xie, C. Liu, Compressive failure modes and parameter optimization of the trabecular structure of biomimetic fully integrated honeycomb plates, Mater. Sci. Eng. C, 69 (2016), 255-261, doi:10.1016/j.msec.2016.06.087

${ }^{16}$ M. Bourada, A. Tounsi, M. S. A. Houari, E. A. A. Bedia, A new four-variable refined plate theory for thermal buckling analysis of functionally graded sandwich plates, J. Sand. Struct. Mater., 14 (2011), 5-33, doi:10.1177/1099636211426386
${ }^{17}$ S. S. Zyniszewski, B. H. Smith, J. F. Hajjar, S. R. Arwade, B. W. Schafer, Local buckling strength of steel foam sandwich panels, Thin-Walled Struct., 59 (2012), 11-19, doi:10.1016/j.tws.2012. 04.014

${ }^{18}$ A. Katunin, Vibration-based spatial damage identification in honeycomb-core sandwich composite structures using wavelet analysis, J. Compos. Struct., 118 (2014), 385-391, doi:10.1016/j.compstruct. 2014.08.010

${ }^{19}$ C. Q. Zhao, J. Ma, Assembled honeycombed sheet light empty stomach building and roof structure system, Patent Application no. 200810100745.X, 21 April 2010

${ }^{20}$ C. Q. Zhao, W. D. Zheng, J. Ma, Y. J. Zhao, Lateral compressive buckling performance of aluminum honeycomb panels for long-span hollow core roofs, Materials, 9 (2016), 444, doi:10.3390/ma9060444

${ }^{21}$ C. Q. Zhao, W. D. Zheng, J. Ma, Y. J. Zhao, Shear strength of different bolt connectors on large span aluminium alloy honeycomb sandwich structure, Appl. Sci., 7 (2017), 450, doi:10.3390/ app7050450

${ }^{22}$ C. Q. Zhao, Y. J. Zhao, J. Ma, The stability of new single-layer combined lattice shell based on aluminum alloy honeycomb panels, Appl. Sci., 7 (2017), 1150, doi:10.3390/app7111150

${ }^{23} \mathrm{H}$. Wang, B. Yuan, Nonlinear geometrical stability analysis of single-layer aluminum alloy reticulated spherical shells, Journal of Guangdong University of Technology, 20 (2003) 3, 1-4

${ }^{24}$ G. Q. Gui, Y. E. Wang, Nonlinear stability analysis of single-layer aluminum alloy reticulated spherical shells, Eng. Mech., 23 (2006), 32-35

${ }^{25}$ H. B. Liu, Y. Z. Ding, Z. H. Chen, Static stability behavior of aluminum alloy single-layer spherical latticed shell structure with Temcor joints, Thin-Walled Struct., 46 (2017), 82-89, doi:10.1016/ j.tws.2017.09.019

${ }^{26}$ K. Sugizaki, S. Kohmura, Y. Hangai, Experimental study on structural behaviour of an aluminum single-layer lattice shell, Trans. AIJ, 61 (1996), 113-122, doi:10.3130/aijs.61.113_1

${ }^{27}$ Y. Hiyama, H. Takashima, T. Iijima, Experiments and analyses of unit single-layer reticular domes using aluminum ball joints for the connections, Trans. AIJ, 64 (1999), 33-40, doi:10.3130/aijs.64.33_1

${ }^{28}$ H. N. Guo, Z. Xiong, Y. F. Luo, Block tearing and local buckling of aluminum alloy gusset joint plates, KSCE J. Civ. Eng., 20 (2016), 820-831, doi:10.1007/s12205-015-1614-3

${ }^{29}$ Z. C. Zhang, X. D. Wang, Structural design and analysis of aluminum dome for Caofeidian coal storage, Key Eng. Mater., 710 (2016), 396-401, doi:10.4028/www.scientific.net/KEM.710.396

${ }^{30}$ M. M. Attard, G. W. Hunt, Sandwich column buckling: A hyperelastic formulation, J. Solids Struct., 45 (2008), 5540-5555, doi:10.1016/j.ijsolstr.2008.05.022

${ }^{31}$ A. Boudjemai, R. Amri, A. Mankour, H. Salem, M. H. Bouanane, D. Boutchicha, Modal analysis and testing of hexagonal honeycomb plates used for satellite structural design, Mater. Des., 35 (2012), 266-275, doi:10.1016/j.matdes.2011.09.012

${ }^{32}$ B. Ravishankar, B. V. Sankar, R. T. Haftka, Homogenization of integrated thermal protection system with rigid insulation bars, Proc. of the $51^{\text {st }}$ AIAA/ASCE/AHS/ASC Structures, Structural Dynamics and Materials Conference, Orlando, USA, 12-15 April 2010; American Institute of Aeronautics and Astronautics: Boston, MA, USA, 2010

${ }^{33}$ Beijing Institute of Mechanics, Chinese Academy of Sciences. Stability and vibration of sandwich plates, Science Press, Beijing 1977, 83-89

${ }^{34}$ L. J. Gibson, M. F. Ashby, Cellular solids: structure and properties, Cambridge University Press, Cambridge 1987, 132-137 